\title{
Prospek Introduksi Regulon nif dari Bakteri Klebsiella pneumoniae ke Dalam Genom Mitokondria Tanaman
}

\section{Prospect of nif Regulon Introduction from Klebsiella pneumoniae Bacteria into Plant Mitochondrial Genome}

\section{Ivan Tjahja Pranata*, Adminarwati Hulu, dan Yoga Aji Handoko}

Program Studi Agroteknologi, Fakultas Pertanian, Universitas Kristen Satya Wacana

Jln. Diponegoro No. 52-60, Salatiga, 50711, Telp. +62298321212

*email: $\underline{512015002 @ \text { student.uksw.edu }}$

\begin{abstract}
Use of synthetic fertilizers bring environmental pollution, increase weed growth, reduce atmospheric oxygen levels, decrease the fertility of agricultural land, causing eutrophication and run-offs, also even damaging coral reefs. Recent biotechnology approaches can be utilized to create a new variety of self-fertilization plants that allows it to supply its own nitrogen making it possible to overcome nitrogen problems and avoid them. This review aims to understand how far genetic engineering approach can be used by the introduction of nif regulon from Klebsiella penumoniae. The nitrogenase-encoding genes which make up the nif regulon proved can be inserted into the mitochondrial genome as like Allen et al. (2017) did in their research. The western blotting result showed that the research succesfully integrated the nif regulon to the genome and expressed their proteins.
\end{abstract}

Keyword: nif regulon, nitrogenase enzym, Klebsiella pneumoniae, mitochondrial genome

Disubmit :11 Mei 2018 ; Diterima : 15 Juli 2018 ; Disetujui : 08 Agustus 2018

\section{PENDAHULUAN}

Nitrogen merupakan salah satu unsur makro yang memiliki peranan penting dalam proses pertumbuhan tanaman (Dixon \& Kahn 2004). Unsur ini sering dipenuhi dengan penggunaan pupuk anorganik urea dan pupuk-pupuk nitrogen lainnya. Namun, pupuk sintetis seperti ini sebenarnya merusak kualitas lahan apabila dipakai secara terus menerus. Selama ini, penggunaan pupuk sintetis berdampak pada banyaknya residu yang menempel pada bagian tanaman yang bisa ikut termakan, sehingga dapat menyebabkan penyakit karena pengendapan senyawa-senyawa kimia. Pupuk sintetis juga menurunkan kesuburan lingkungan mikro, karena residu yang tertinggal di tanah menyebabkan beberapa mikroorganisme dalam tanah menjadi mati, sehingga tidak dapat mengurai bahan-bahan tersisa. Sebagai contoh, pupuk urea terbukti menjadikan tanah semakin keras, tidak gembur, dan sulit untuk ditanami (Rosmarkam \& Yuwono 2002). Cui et al. (2013) juga mengemukakan bahwa 50\% dari total pupuk $\mathrm{N}$ yang diberikan ke tanaman ternyata tidak terserap. Hal ini memicu run-off senyawa kimia dalam pupuk sehingga mengotori lingkungan, memicu pertumbuhan gulma lebih banyak, dan eutrofikasi pada jalur perairan (Good \& Beatty 2011). Memicu pertumbuhan gulma berarti juga meningkatkan ketergantungan petani terhadap pengunaan herbisida. Lebih jauh, run-off dari pupuk ini juga memicu pertumbuhan agal blooms yang mereduksi jumlah oksigen di udara dan juga merusak terumbu karang. Bertolak belakang dari fakta-fakta itu, banyak petani di berbagai negara justru kekurangan pupuk sehingga membatasi pertumbuhan tanaman budidaya mereka (Mueller et al. 2012). 
Berdasarkan hal-hal tersebut, beberapa penelitian terbaru mencoba merakit tanaman yang dapat menyuplai nitrogennya sendiri sehingga mengurangi ketergantungan pada penggunaan pupuk. Penulisan artikel review (ulasan) ini bertujuan untuk mengetahui sejauh mana perkembangan penelitian terbaru dalam usaha menciptakan varietas tanaman baru yang mampu mensuplai nitrogennya sendiri (nitrogen selffertilized plants).

Beberapa Pendekatan, dari Metode BNF hingga Introduksi Gen. Ivleva et al. (2016) mengutarakan adanya 3 pendekatan yang dapat dilakukan agar tanaman mampu menghasilkan nitrogen tanpa input pupuk. Pendekatan pertama ditempuh melalui metode biological nitrogen fixation (BNF), yang secara alamiah terjadi di alam, seperti pada tanaman Leguminosae yang bersimbiosis dengan bakteri penambat nitrogen Rhizobium yang membentuk nodul pada akar tanaman. Melalui metode BNF, tanaman Leguminosae dapat ditumpangsarikan dengan tanaman serealia sebagai suplai nitrogen. Pendekatan kedua ditempuh dengan cara introduksi gen yang mensintesis nitrogenase ke dalam bakteri endofit yang diketahui berinteraksi dengan akar tanaman. Pendekatan ketiga dilakukan dengan mengintroduksikan gen yang berperan dalam fiksasi nitrogen secara langsung ke dalam genom tanaman sehingga tanaman dapat mendapat suplai nitrogen secara self-fertilizing. Oldroyd dan Dixon (2014) berpendapat bahwa pendekatan dengan cara introduksi ini dapat ditempuh melalui dua kemungkinan, yang pertama adalah dengan menyisipkan gen yang menyandi faktor nod sehingga tanaman dapat menjadi bersimbiosis dengan Rhizobium dan membentuk nodul, kemudian yang kedua adalah dengan langsung menyisipkan gen yang menyintesis nitrogenase ke dalam genom tanaman.

Pendekatan dengan metode introduksi dinilai paling efektif untuk menggantikan peran pupuk sintetis karena beberapa tanaman ternyata tidak compatible dengan pengaplikasian bakteri penambat nitrogen ataupun pupuk hayati apabila dibandingkan dengan penggunaan metode BNF. Hasil penelitian dari Bhuvaneshwari dan Singh (2015) membuktikan bahwa pemanfaatan Azolla sebagai biofertilizer tidak memberikan peningkatan produksi tanaman kedelai secara signifikan. Mayani dan Hapyoh (2011) juga melaporkan hal serupa bahwa pemakaian Rhizobium hasil "introduksi" tidak memberikan perbedaan hasil yang nyata pada produksi biji kedelai dibandingkan dengan perlakuan tanpa Rhizobium. Pendekatan dengan metode BNF, dimana nitrogen difiksasi melalui bakteri-bakteri nonmodul pada perakaran tanaman, juga mengalami kelemahan. Hal ini dibuktikan oleh Reddy et al. (2002) yang melaporkan bahwa indigenous BNF hanya menaikkan produksi tanaman padi hingga berhenti di tingkat 4 ton/ha saja. Angka ini tentunya berbanding jauh bila dibandingkan dengan kemampuan bakteri nodul untuk menambat nitrogen sebanyak $458 \mathrm{~kg}$ N/ha pada tanaman Leguminosae (Herridge et al. 1990). Berdasarkan bukti-bukti di atas, pendekatan melalui introduksi langsung ke dalam genom tanaman dinilai sangat prospek dan efektif untuk merakit varietas tanaman yang dapat menambat nitrogen sendiri tanpa pupuk dan bantuan bakteri secara langsung yang populasinya tidak terprediksi di setiap waktu.

Proses Fiksasi Nitrogen. Fiksasi nitrogen adalah proses pengubahan gas nitrogen bebas $\left(\mathrm{N}_{2}\right)$ menjadi bentuk yang tersedia yaitu amonium $\left(\mathrm{NH}_{4}{ }^{+}\right)$. Bentuk amonium inilah yang dibutuhkan oleh tanaman sebagai unsur makro untuk proses pertumbuhannya. Namun, proses fiksasi nitrogen ini tidak pernah terjadi pada organisme eukariotik manapun karena kemampuan tersebut hanya dimiliki oleh beberapa jenis bakteri saja (Rosmarkam \& Yuwono 2002).

Proses fiksasi nitrogen secara alamiah dapat dengan mudah diamati pada tanaman Leguminosae yang mengalami simbiosis dengan bakteri Rhizobium. Tanaman-tanaman yang termasuk dalam kelompok tersebut biasanya memiliki nodul seperti tumor ( $\mathrm{g}$ all). Nodul ini terbentuk ketika rambut akar tanaman mengalami diinfeksi oleh bakteri Rhizobium. Bakteri ini sebenarnya bersifat sebagai parasit karena mengambil energi untuk pertumbuhan dari tanaman inang. Meskipun demikian, saat mengalami pertumbuhan di dalam sel akar yang terinfeksi bakteri ini juga memfiksasi nitrogen bebas di udara menjadi bentuk yang tersedia bagi tanaman, sehingga memberikan keuntungan agronomis. Hampir sama dengan Rhizobium, bakteri 
Azotobacter juga memfiksasi nitrogen bebas di udara tetapi tidak bersimbiosis dengan tanaman melainkan hidup bebas di udara (Madigan et al. 2009).

Enzim Nitrogenase dalam Klebsiella pneumoniae. Pengikatan nitrogen bebas yang dilakukan oleh bakteri dikerjakan oleh suatu enzim yang dinamakan enzim nitrogenase (Bauman 2015). Enzim ini adalah enzim kompleks berukuran besar yang diatur oleh lebih dari 1 gen dan memiliki inti berupa kofaktor Femoco seperti yang dapat dilihat pada Gambar 1.

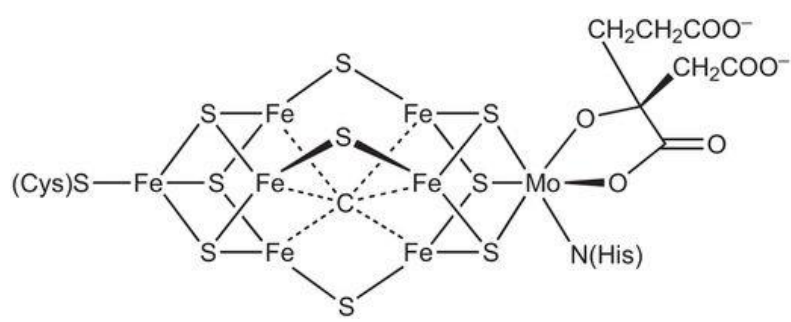

Gambar 1. Struktur Kimia dari Molekul Kofaktor Femo-co

Pada bakteri Klebsiella pneumoniae, bakteri yang paling sering dipelajari dalam konteks fiksasi nitrogen, ditemukan sekitar 17-20 gen yang letaknya berdekatan (Madigan et al. 2015). Uniknya gen-gen tersebut ternyata tidak terpencar-pencar, melainkan terkelompok ke dalam suatu sekuens DNA yang disebut sebagai regulon nif dan hanya diselingi oleh beberapa ORF (open reading frame) saja yang belum diketahui fungsinya (Hajoeningtijas 2012). Hal ini tentunya memudahkan peluang regulon tersebut untuk disisipkan ke genom tanaman budidaya sehingga tiap individu tanaman dapat menghasilkan nitrogen sendiri.

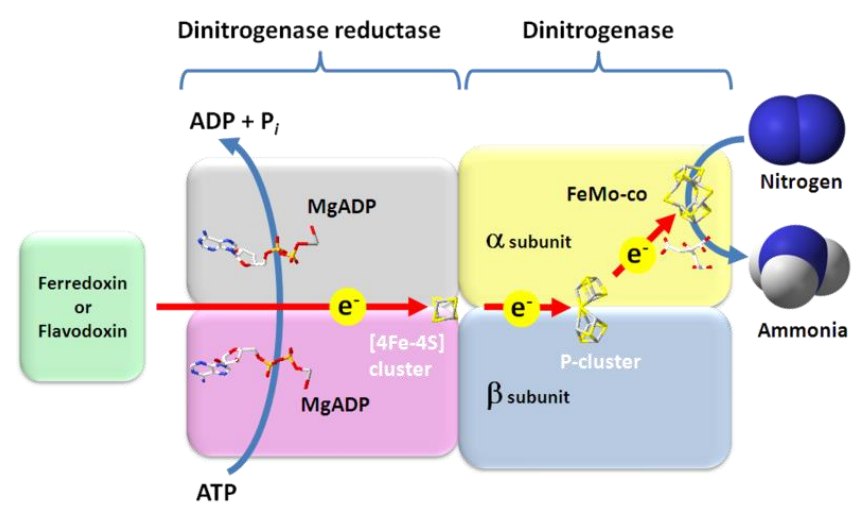

Gambar 2. Skema masuknya elektron dalam subunit dinitrogenase reduktase dan subunit dinitrogenase hingga menghasilkan amonium.

Enzim kompleks nitrogenase sendiri terdiri dari dua bagian yaitu dinitrogenase dan dinitrogenase reduktase (Gambar 2). Keduanya mengandung molekul Fe, sedangkan khusus enzim dinitrogenase juga mengandung molekul Mo (Madigan et al. 2015). Molekul Fe dan Mo ini sesungguhnya adalah bagian dari kofaktor FeMo-co yang terintegrasi pada struktur molekul enzim dinitrogenase sebagai situs aktif. Proses fiksasi nitrogen yang melibatkan reaksi hidrogenasi oleh nitrogenase terjadi pada situs aktif FeMo-co ini (Dance 2016). Berdasarkan hasil penelitian yang dilakukan oleh Peters dan Szilagyi (2006), pembentukan kofaktor FeMo-co ini dibantu oleh senyawa MgATP. Rumus struktur dari FeMo-co adalah $\mathrm{MoFe}_{7} \mathrm{~S}_{8^{-}}$ homositrat (Madigan et al. 2015).

Persamaan net reaction dari fiksasi nitrogen secara utuh dirumuskan oleh Madigan et al. (2015) menurut persamaan berikut ini: 


$$
\mathrm{N}_{2}+8 \mathrm{H}^{+}+8 \mathrm{e}^{-}+16 \mathrm{ATP} \rightarrow 2 \mathrm{NH}_{3}+\mathrm{H}_{2}+16 \mathrm{ADP}+16 \mathrm{P}_{\mathrm{i}}
$$

Net reaction tersebut sebenarnya mengalami beberapa tahap reaksi reduksi. Madigan et al. (2015) menjelaskan bahwa mula-mula gas dinitrogen di atmosfer yang memiliki ikatan rangkap tiga direduksi menjadi diimine yang memiliki ikatan rangkap dua. Diimine selanjutnya direduksi lagi menjadi hydrazine yang memiliki ikatan rangkap satu. Hydrazine kemudian dipecah menjadi dua molekul amonia kemudian diubah menjadi ion amonium yang dapat diserap dan dipakai oleh tanaman sebagai sumber nutrisi.

Struktur Regulon nif dari Klebsiella pneumoniae. Bakteri Klebsiella pneumoniae sudah sejak lama menjadi bahan studi paling utama dalam mempelajari mekanisme sintesis nitrogenase. Bakteri ini adalah satu-satunya mikroorganisme yang sekuens regulon nif-nya sudah terpetakan (Wang et al. 2013). Ukuran sekuens regulon nif dari Klebsiella pneumoniae kira-kira 24.000 pasangan basa DNA yang tersusun oleh 7 operon yang menyandi 20 gen. Ketujuh operon tersebut adalah nifBQ, nifLA, nifF, nifUSVWZM, nifENX, nifHDKTY, dan nifJ. Selain mengandung gen struktural nitrogenase, regulon nif juga terdiri dari gen untuk sintesis FeMo-co, gen untuk mengendalikan protein dalam transpor elektron, dan beberapa gen regulator. Beberapa fungsi-fungsi tersebut dikerjakan oleh lebih dari 1 operon (Madigan et al. 2015). Susunan peta regulon nif beserta fungsi gennya dapat dilihat pada Gambar 3.

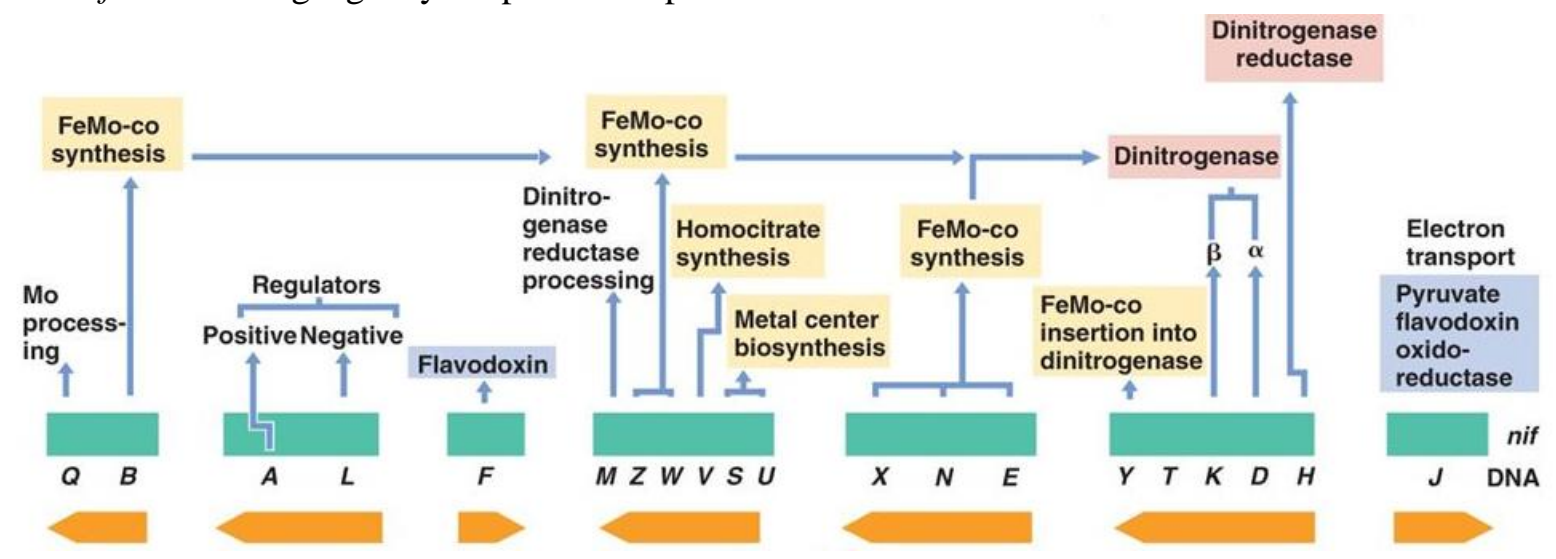

Gambar 3. Susunan 20 gen dan 7 operon yang menyusun regulon nif bakteri Klebsiella pneumoniae. Panah yang ada di bagian bawah gambar melambangkan arah transkripsi dari operon tersebut (Madigan et al. 2015).

Enzim kompleks nitrogenase terdiri dari dua bagian (Peters \& Szilagyi 2006) yaitu dinitrogenase yang disintesis oleh gen nifD dan nifK serta dinitrogenase reduktase yang disintesis oleh gen nifH. Keduanya mengandung molekul Fe dan Mo. Proses sintesis molekul FeMo-co dikendalikan oleh beberapa gen sekaligus yaitu nifB, nifW, nifZ, nifE, nifN, dan nifX. Setelah sintesis Fe dan Mo selesai, molekul-molekul tersebut kemudian diintegrasikan ke dalam protein dinitrogenase melalui kendali gen nifY. Gen nifJ dan nifF berperan dalam proses transpor elektron, dimana nifJ menyandi enzim pryuvate flavodoxin oxidoreductase dan nifF menyandi senyawa flavodoxin (Madigan et al. 2015).

Regulasi Regulon nif. Proses reduksi gas nitrogen $\left(\mathrm{N}_{2}\right)$ di atmosfer menjadi amonium $\left(\mathrm{NH}_{4}{ }^{+}\right)$ membutuhkan sejumlah energi yang besar. Keberadaan oksigen dan bahkan amonium sendiri dapat menjadi penghambat dalam proses tersebut karena bertindak sebagai efektor dalam sinyal inhibisi yang sifatnya irreversible (Madigan et al. 2015). Untuk menghindari terjadinya pemborosan energi, maka aktivasi regulon nif diatur melalui suatu regulasi yang ketat.

Secara alami, sistem regulasi sintesis enzim nitrogenase dikendalikan oleh operon nifLA yang terdiri dari dua gen, yaitu nifA dan nifL. Gen nifA adalah regulator positif untuk memulai proses transkripsi dari regulon nif. Sebaliknya, gen nifL adalah regulator negatif yang mengandung molekul FAD. Regulasi gen nifA sebagai aktivator dari seluruh struktur regulon nif dipengaruhi oleh operon yang lain, yaitu $n t r A B C$. 
Operon ini tidak berada di dalam struktur regulon nif, tetapi bekerja secara bersamaan dengan operon nifLA. Dalam keadaan miskin nitrogen, gen $n t r C$ akan mengalami fosforilasi kemudian mengaktifkan transkripsi dari gen nifA (Madigan et al. 2015). Selanjutnya, protein yang dihasilkan oleh gen nifA bergabung dengan Integration Host Factor (IHF) dan holoenzim- $\sigma 54$ membentuk suatu RNA polimerase yang menginisiasi transkripsi promoter operon nif yang lain (Morett \& Segovia 1993). Gen nifL akan bertindak sebagai represor bagi regulon nif melalui sinyal kelebihan $\mathrm{NH}_{4}{ }^{+}$dan $\mathrm{O}_{2}$ di dalam sel. Dalam kondisi cukup oksigen, gen nifL akan mensintesis protein NifL yang menahan sintesis dari gen-gen nif yang lain. Dalam kondisi dimana amonia terlalu banyak, gen $n t r C$ menjadi tidak terfosforilasi sehingga tidak memicu transkripsi dari gen nifA. Meskipun demikian, Madigan et al. (2015) menjelaskan bahwa amonia yang dihasilkan dari proses fiksasi nitrogen oleh nitrogenase tidak akan menghambat proses sintesis karena terinkorporasi menjadi asam amino.

Proses Penyisipan Gen-gen nif ke Dalam Genom Eukariot. Awal mula penelitian produksi nitrogen secara transgenik dimulai dengan penelitian Dixon dan Postgate (1972) mengenai introduksi gen-gen yang menyandi subunit nitrogenase dari Klebsiella pneumoniae ke dalam Escherichia coli melalui teknik konjugasi. Bakteri E. coli yang mulanya secara alamiah tidak menghasilkan nitrogenase, setelah proses konjugasi selesai menjadi mampu melakukan fiksasi nitrogen.

Penelitian kemudian berlanjut dengan digunakannya vektor Agrobacterium tumefaciens untuk menginisiasi nodul pada tanaman. Martínez et al. (1987) melakukan penelitian dimana plasmid berukuran $410 \mathrm{kbp}$ dari Rhizobium phaseoli CFN299, yang diperkirakan mengandung gen struktural nitrogenase, ditransformasi ke dalam Agrobacterium tumefaciens GMI9023 yang plasmidnya sudah terlebih dulu dikosongkan. Transformasi ini menghasilkan transkonjugan dari Agrobacterium tumefaciens GMI9023 yang membawa plasmid dari Rhizobium phaseoli. Hasil dari penelitian ini memperlihatkan bahwa transkonjugan tersebut berhasil membentuk nodul pada tanaman Phaseolus vulgaris dan Leucaena esculenta tanpa perlu bersimbiosis dengan Rhizobium. Penelitian ini sayangnya tidak memberikan dampak positif karena bintil tersebut tidak bisa mengikat nitrogen.

Penelitian terkini diarahkan pada penyisipan regulon nif secara langsung ke dalam genom tanaman. Bruijn (2016) mengemukakan bahwa upaya-upaya untuk menyisipkan regulon nif ke dalam genom tanaman mulai berkembang pesat sejak ditemukannya gen-gen yang berperan dalam sintesis FeMo-co. Dari sini para peneliti bioteknologi mengetahui mekanisme pembentukan enzim kompleks nitrogenase dalam melakukan fiksasi nitrogen setelah sekuens-sekuens gen nif diketahui.

Hambatan Introduksi Regulon nif. Kesulitan pertama dalam mengintroduksikan regulon nif yang menyandi enzim kompleks nitrogenase ke dalam genom tanaman adalah persoalan banyaknya gen-gen yang berperan dalam proses sintesis di dalamnya. Oleh karena rumit dan perlu diekspresikan pada rasio yang tepat (Dixon \& Postgate 1972), maka untuk melakukan proses introduksi tersebut diperlukan vektor yang besar. Selain itu, ketepatan ekspresi transgen dalam jumlah yang besar pada tanaman dapat menjadi kendala serius. Kesulitan seperti ini sebenarnya dapat diatasi dengan melakukan hacking pada struktur molekul DNA Agrobacterium. Berdasarkan penelitian yang dilakukan oleh Miranda et al. (1992), pemindahan banyak gen menggunakan Agrobacterium hingga 200.000 bp dapat dimediasi dengan cara membalik arah orientasi dari ujung kanan T-DNA. Melalui cara ini maka sangat dimungkinkan menyisipkan regulon nif yang berukuran 24.000 bp (Madigan et al. 2015) ke dalam T-DNA region Agrobacterium yang sudah dibalik yang berukuran 200.000 bp (Miranda et al. 1992).

Kesulitan yang kedua adalah hambatan fisiologis dari inhibitor enzim nitrogenase. Enzim kompleks yang befungsi untuk melakukan fiksasi nitrogen ini sangat sensitif terhadap oksigen, terutama ketika terpapar oleh udara (Shah \& Brill 1973). Keberadaan oksigen dapat menjadi inhibitor yang bersifat irreversible bagi enzim nitrogenase, padahal tanaman sendiri adalah penghasil oksigen di biosfer. Dengan demikian, diperlukan strategi khusus agar ekspresi nitrogenase pada sel tanaman dapat dioptimalkan. 
Selain kesulitan pertama dan kedua, terdapat kesulitan ketiga yakni permasalahan regulator dari sistem transkripsi regulon nif. Seperti yang telah diketahui, aktivator dari regulon nif ditentukan dari transkripsi gen aktivator nifA. Apabila nifA tidak teraktivasi, maka seluruh struktur gen yang tergabung dalam regulon nif juga tidak akan terekspresi. Kegagalan proses transformasi operon nifLA akan berakibat pada tidak terekspresinya enzim nitrogenase walaupun bagian struktur gen nif yang lain tersisip ke dalam genom tanaman (Wang et al. 2013).

Genom Mitokondria sebagai Target Penyisipan. Dalam beberapa tahun terakhir ini, terdapat dua percobaan untuk mengintroduksikan gen-gen nif secara massal. Keduanya sama-sama menggunakan pendekatan biologi sintetik yaitu pembuatan promoter dan terminator sintetik pada tiap-tiap sekuens yang akan disisipkan. Ivleva et al. (2016) memilih genom plastida sebagai target penyisipan, sedangkan Allen et al. (2017) memilih genom matriks mitokondria untuk targetnya. Pembahasan selanjutnya dalam tulisan ini akan difokuskan pada penelitian Allen et al. (2017) yang mana hasil tingkat ekspresi protein nitrogenasenya lebih tinggi dan efektif.

Genom matriks mitokondria dipilih sebagai target penyisipan karena beberapa alasan. Pertama, mitokondria menggunakan oksigen untuk respirasi sel sehingga menurut Curatti dan Rubio (2014) lokasi ini cocok untuk penyisipan gen-gen nif yang sistem ekspresinya dihambat oleh adanya oksigen. Kedua, gen-gen pada mitokondria terlibat dalam sintesis metaloenzim, sehingga menurut Balk dan Pilon (2011) kemungkinan assembly protein-nya mirip dengan yang digunakan untuk sintesis nitrogenase. Hal ini dikuatkan oleh pendapat Jiménez-Vicente et al. (2015) yang menyatakan bahwa beberapa produk dari gengen yang berperan dalam sintesis FeMo-co dapat digantikan oleh counterpart (semacam senyawa lain) pada mitokondria tanaman yang akan disisipi.

Strategi Penyisipan Regulon nif ke dalam Genom Mitokondria. Beberapa pendekatan biologi sintetik sudah dilakukan untuk memodifikasi mekanisme penyisipan regulon nif ke dalam tanaman. Pendekatan biologi sintetik yang dimaksudkan disini adalah rekayasa biomolekuler. Penelitian pendahuluan dilakukan oleh Wang et al. (2013) yang mencoba menyisipkan seluruh gen-gen yang termasuk dalam regulon nif untuk disisipkan ke dalam genom bakteri Eschericia coli. Tujuannya adalah mengekspresikan gen-gen nif tersebut pada bakteri tanpa bergantung pada kendali operon nifLA. Pada Gambar 4. dapat dilihat bagaimana struktur konstruksi gen yang dirancang oleh Wang et al. (2013).

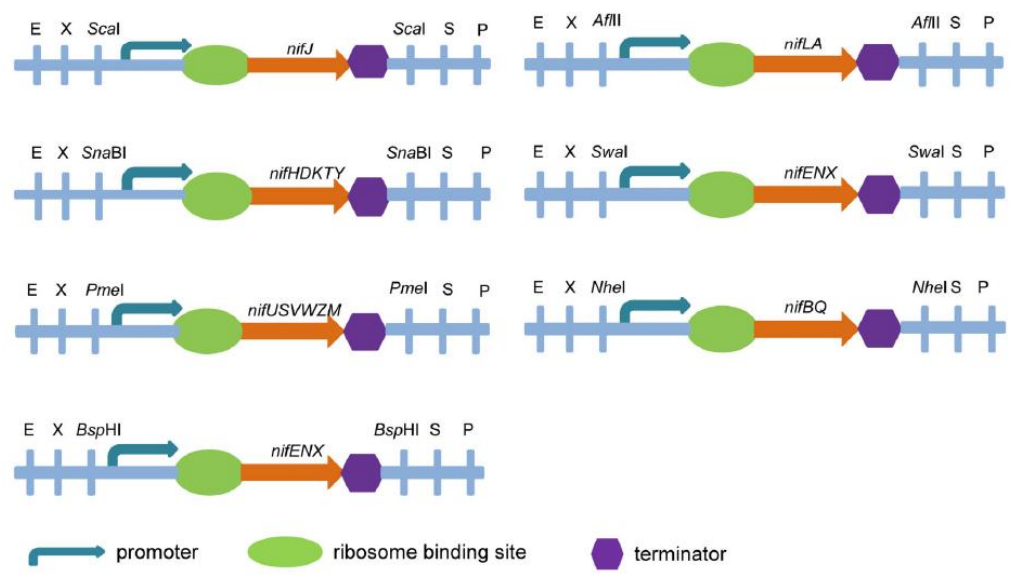

Gambar 4. Tiap-tiap operon yang menyusun regulon nif dibuatkan promoter dan terminator, sehingga tidak tergantung pada regulasi dari operon nifLA. Gen nifL dan nifA masih diikutkan dalam penyisipan gen, meskipun tidak memiliki fungsi lagi (Wang et al. 2013).

Pada rancangan struktur penyisipan yang dikerjakan oleh Wang et al. (2013), tiap-tiap operon dari regulon nif dibuatkan promoter dan terminator melalui metode potong dan tempel menggunakan berbagai macam enzim restriksi dan enzim ligase. Meskipun demikian, dalam penelitiannya operon nifLA masih 
Pranata, dkk: Prospek Introduksi Regulon nif dari Bakteri Klebsiella pneumoniae ke Dalam Genom Mitokondria...

diikutkan dalam penyisipan gen. Ketujuh operon ini nantinya akan disisipkan ke dalam vektor yang terdapat pada Agrobacterium.

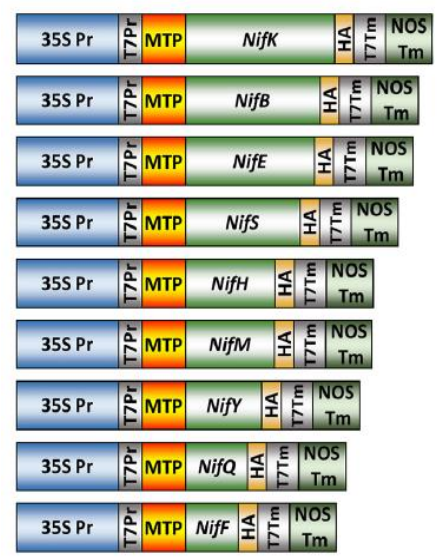

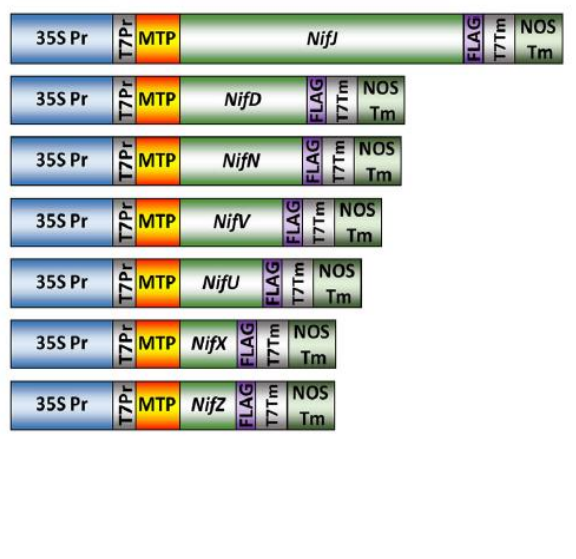

Gambar 5. Tiap-tiap gen yang menyusun regulon nif dibuatkan 2 promoter dan 2 terminator, sehingga tidak tergantung pada regulasi dari operon nifLA. Gen nifL dan nifA sudah tidak diikutkan dalam penyisipan gen (Wang et al. 2013)

Gambar 5. di atas menunjukan konstruksi gen yang dirancang oleh Allen et al. (2017). Perbedaannya dibandingkan dengan konstruksi yang dirancang oleh Wang et al. (2013) terletak pada individu yang dibuatkan promotor dan terminator sintetis. Dalam konstruksi rancangan Allen et al. (2017), tiap gen nif masing-masing dibuatkan 2 promoter dan 2 terminator. Promoter tersebut adalah 35S promoter dan T7 promoter, sedangkan terminatornya adalah $\mathrm{T} 7$ terminator dan NOS terminator.

Proses konstruksi gen yang dilakukan oleh Allen et al. (2017) mula-mula memanfaatkan plasmid pET14b. Plasmid ini digunakan untuk membentuk T7 Promoter dan T7 Terminator, lalu dari bagian tersebut disisipi dengan T-DNA dari pORE1 di antara bagian 35S Promoter dan NOS Terminator. Gabungan dari kedua plasmid ini menghasilkan plasmid rekombinan pCW441. Sekuens MTP (Mitochondrial Targeting Peptide) dan HA/FLAG kemudian ditambahkan pada plasmid pCW441 menghasilkan plasmid rekombinan baru yaitu plasmid pRA1. MTP digunakan untuk mengarahkan gen-gen nif ke dalam mitrokondria, sedangkan sekuens HA dan FLAG digunakan sebagai probe untuk menandai keberadaan protein hasil ekspresi pada saat dilakukan western blotting. Promoter 35S tergolong ke dalam jenis promoter konsitutif yang memungkinkan sebuah gen diekspresikan secara terus-menerus tanpa memperhatikan kondisi lingkungannya. Perpaduan promoter ini dengan promoter T7 memungkinkan gen-gen dari regulon nif diekspresikan secara besar-besaran. Proses pemotongan dan penempelan fragmen-fragmen plasmid-plasmid tersebut menggunakan berbagai macam enzim endonuklease restriksi tipe II dan enzim ligase. Sebagai contoh, penempelan MTP pada plasmid pCW441 menggunakan enzim restriksi NotI dan AscI. Sekuens GFP diambilkan dari sekuens GPF S65T kemudian digabungkan bersama sekuens MTP sebelum dilekatkan pada pCW441. Konstruksi sekuens mula-mula sebelum disisipin dengan gen-gen nif dapat dilihat pada Gambar 6.

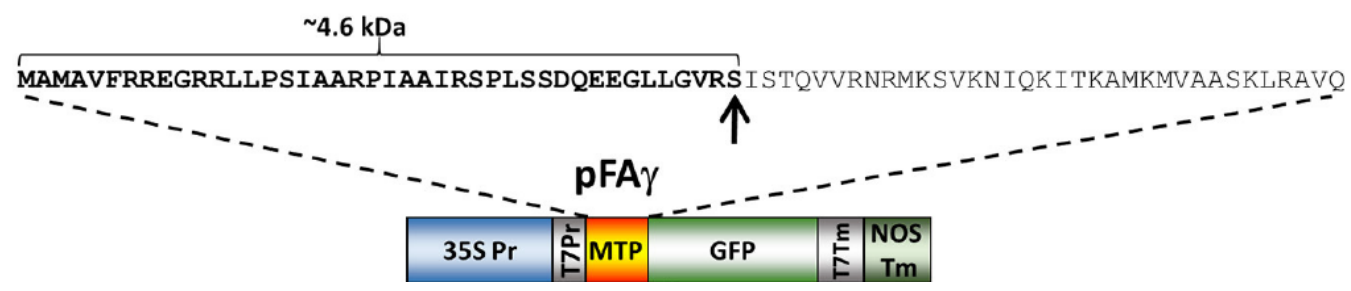

Gambar 6. Kontruksi sekuens mula-mula sebelum disisipi dengan gen-gen nif (Allen et al. 2017). 
Dalam penelitian Allen et al. (2017), juga dicoba membuat stacking atau linking gen. Sebagai contoh nifD dihubungkan dengan nifK. Tujuan dari linking ini adalah mengetahui efisiensi dari ekspresi gen yang digabung dibandingkan dengan ekspresi gen tunggal. Gambar 7A memaparkan hasil ekspresi protein dari nifD tunggal, nifK tunggal, dan nifD yang dilinker dengan nifK. Tampak, bahwa nifD yang dilinker dengan nifK berhasil terekspresi dengan ukuran yang lebih besar daripada gen tunggal nifD dan nifK.
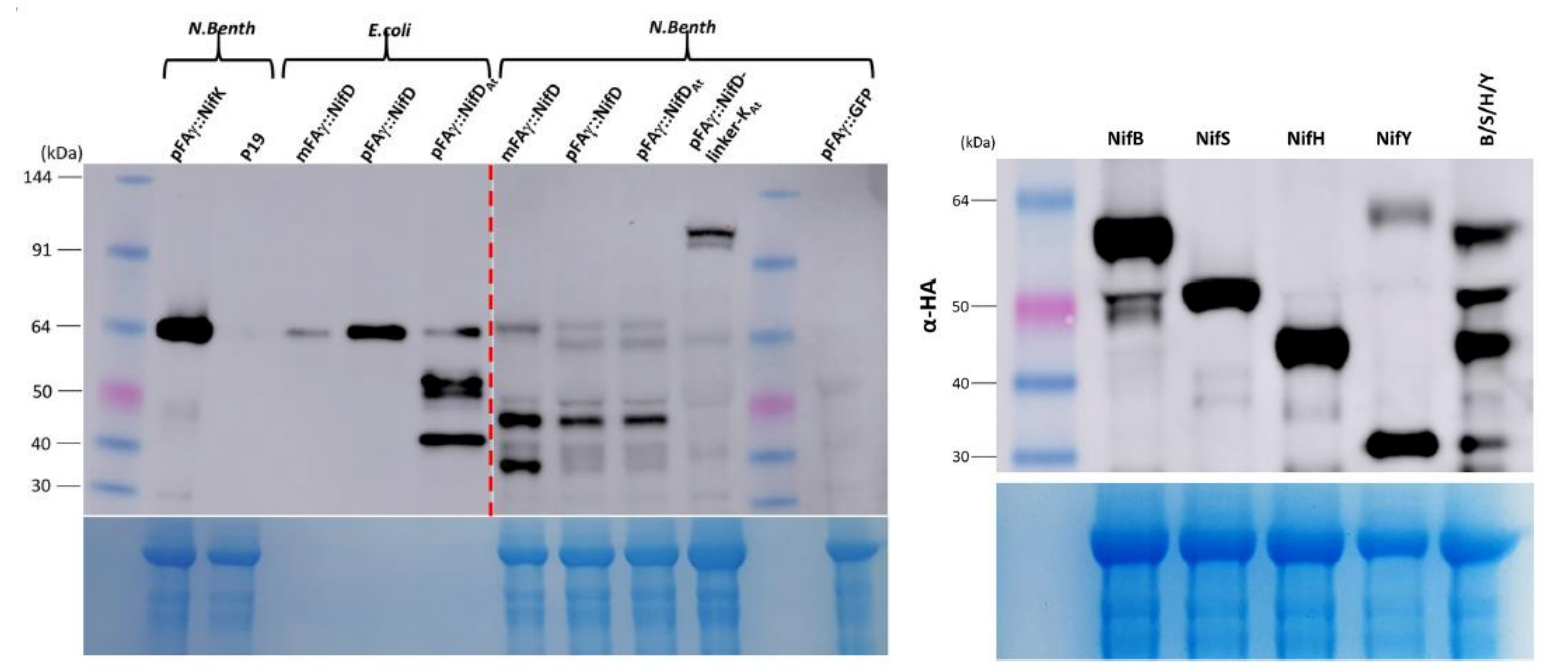

Gambar 7. (A) Hasil ekspresi tunggal gen nifD, nifK, dan nifD yang dilinker dengan nifK pada tanaman uji Nicotiana benthamiana. (B) Hasil ekspresi tunggal gen nifD, nifK, dan nifD yang dilinker dengan nifK pada tanaman uji Nicotiana benthamiana (Allen et al. 2017).

Walaupun berhasil terekspresi, Allen et al. (2017) membuktikan bahwa jumlah gen tunggal yang terkepresi jauh lebih banyak daripada gen-gen yang dilinker. Hal ini dibuktikan pada saat dicoba melakukan stacking terhadap 4 gen sekaligus yaitu gen nifB, nifS, nifH, dan nifY. Hasil ekspresi keempat gen-gen tunggal tersebut ternyata jauh lebih banyak jumlahnya daripada hasil ekpresi stacking gen nifBSHY, seperti yang ditunjukkan pada Gambar 7B.

Hasil Analisis Ekspresi Enzim Nitrogenase. Allen et al. (2017) membuktikan bahwa konstruksi yang dibuatnya berhasil menyisipkan semua gen-gen nif ke dalam tanaman uji Nicotiana benthamiana. Meskipun demikian, jumlah dari tiap-tiap gen yang tersisip bervariasi. Gen-gen yang berhasil terekspresi dalam jumlah besar adalah nifK, nifB, nifS, nifH, nifY, nifJ, nifN, nifV, nifU, nifX, nifZ, nifD, dan nifU. Pada Gambar 8. dapat dilihat bahwa hasil western blotting dari gen-gen tersebut membentuk blot hitam besar yang menunjukkan bahwa protein-protein dari gen tersebut ditemukan dalam jumlah besar.

Gen nifA dan nifL tidak terekspresi karena memang sengaja tidak disisipkan. Adapun gen-gen yang terekspresi tetapi dalam jumlah yang sangat sedikit adalah nifE, nifM, nifQ, dan nifF yang ditunjukkan oleh hasil blotting berupa awan tipis. Gen-gen nifJ, nifN, nifV, nifU, nifX, nifZ, nifD, dan nifU variabilitasnya masih sangat banyak. Variabilitas ini dimungkinkan oleh hasil ekpresi yang masih kurang murni, sehingga beberapa gen masih belum membentuk blotting hitam yang kompak. Allen et al. (2017) juga berpendapat bahwa nifD perlu dirancang ulang agar dapat terekspresi dalam jumlah yang lebih banyak dikarenakan gen ini adalah salah satu gen kunci untuk sintesis enzim nitrogenase. 
Pranata, dkk : Prospek Introduksi Regulon nif dari Bakteri Klebsiella pneumoniae ke Dalam Genom Mitokondria ...
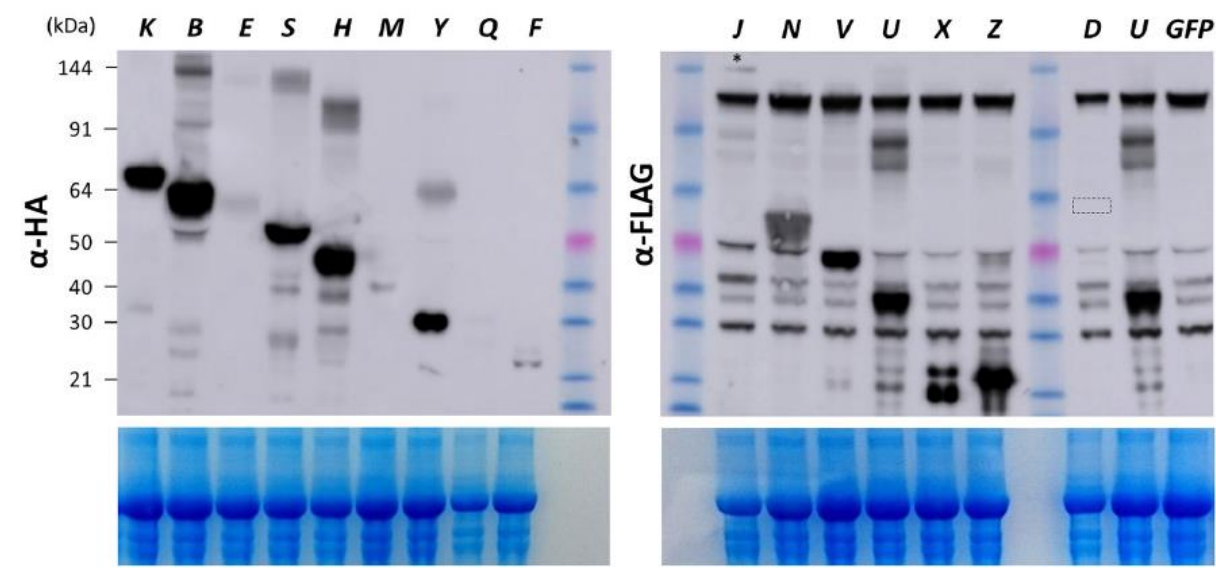

Gambar 8. Hasil ekspresi protein-protein Nif pada tanaman uji Nicotiana benthamiana berdasarkan uji western blotting (Allen et al. 2017).

\section{KESIMPULAN}

Perkembangan perakitan tanaman yang mampu mensuplai nitrogen sendiri sudah pada tahapan keberhasilan ekspresi protein, yakni tanaman yang diujikan mampu mengekspresikan nitrogenase melalui penyisipan gen-gen yang tersusun dalam regulon nif ke dalam genom mitokondria tanaman uji Nicotiana benthamiana. Meskipun demikian, penelitian ini masih perlu diujicobakan pada tanaman komersial, kemudian setelah selesai dirancang masih perlu dilanjutkan untuk pengujian multilokasi di lapangan, dan hasilnya dibandingkan dengan tanaman yang dipupuk secara konvensional.

\section{DAFTAR PUSTAKA}

Allen, R.S., Tilbrook, K., Warden, A.C., Campbell, P.C., Rolland, V., Singh, S.P. \& Wood, C.C., 2017. Expression of 16 nitrogenase proteins within the plant mitochondrial matrix. Frontiers in Plant Science, 8, article 287. Available at: https://doi.org/10.3389/fpls.2017.00287.

Balk, J. \& Pilon, M., 2011. Ancient and essential: the assembly of iron-sulfur clusters in plants. Trends Plant Science, 16, pp.218-226. Available at: https://doi.org/10.1016/j.tplants.2010.12.006.

Bauman, R.W. 2015. Microbiology with Diseases by Body System. $4^{\text {th }}$ Edition. San Fransisco: Pearson Benjamin-Cummings.

Bhuvaneshwari, K. \& Singh, P.K., 2015. Response of nitrogen-fixing water fern Azolla biofertilization to rice crop. 3 Biotech, 5, pp.523-529. Available at: https://doi.org/10.1007/s13205-014-0251-8.

Bruijn, Frans J. de. 2016. “'Biological Nitrogen Fixation' Book Summary.” Advances in Microbiology 6 (6). Scientific Research Publishing: 407-11. Available at: https://doi.org/10.4236/aim.2016.66040.

Cui, S., Shi, Y., Groffman, P.M., Schlesinger, W.H. \& Zhu, Y.G., 2013. Centennial-scale analysis of the creation and fate of reactive nitrogen in China (1910-2010). Proceedings of the National Academy of Sciences 110(6), pp.2052-2057. Available at: https://doi.org/10.1073/pnas.1221638110.

Curatti, L. \& Rubio, L.M., 2014. Challenges to develop nitrogen fixing cereals by direct nif-gene transfer. Plant Science, 225, pp.130-137. Available at: https://doi.org/10.1016/J.PLANTSCI.2014.06.003.

Dance, Ian. 2016. Mechanisms of the S/CO/Se interchange reactions at FeMo-Co, the active site cluster of nitrogenase. Dalton Transactions, 45(36), pp.14285-14300. Available at: https://doi.org/10.1039/ C6DT03159E. 
Dixon, R.A. \& Postgate, J.R., 1972. Genetic transfer of nitrogen fixation from Klebsiella pneumoniae to Escherichia coli. Nature, 237, pp.102-103. Available at: http://www.ncbi.nlm.nih.gov/pubmed/ 4555442.

Dixon, R.A \& Kahn, D., 2004. Genetic regulation of biological nitrogen fixation. Nature Reviews Microbiology, 2, pp.621-631. Available at: https://doi.org/10.1038/nrmicro954.

Good, A.G. \& Beatty, P.H., 2011. Fertilizing nature: a tragedy of excess in the commons. PLoS Biology, 9, pp.e1001124. Available at: https://doi.org/10.1371/journal.pbio.1001124.

Hajoeningtijas, O.D. 2012. Mikrobiologi Pertanian. Yogyakarta: Graha Ilmu.

Herridge, D.F., Bergersen, F.J. \& Peoples, M.B., 1990. Measurement of nitrogen fixation by soybean in the field using the ureide and natural ${ }^{15} \mathrm{~N}$ abundance methods. Plant Physiology, 93, pp.708-716. Available at: http://www.ncbi.nlm.nih.gov/pubmed/16667527.

Ivleva, N.B., Groat, J., Staub, J.M. \& Stephens, M., 2016. Expression of active subunit of nitrogenase via integration into plant organelle genome. PloS ONE, 11(8), pp.e0160951. Available at: https://doi.org/10.1371/journal.pone.0160951.

Jimenez-Vicente E, Hernandez JA, Echavarri-Erasun C, Rubio LM. 2015. Biosynthesis of the IronMolybdenum Cofactor of Nitrogenase. In: de Bruijn FJ. (ed). Biological Nitrogen Fixation. Hoboken: Wiley-Blackwell Publishers. pp 75-86.

Madigan, M.T., Martinko, J.M., Bender, K.S., Buckley, D.H. \& Stahl, D.A.. 2015. Brock Biology of Microorganisms, 14th Edition. Boston: Pearson.

Martínez, E., Palacios, R., \& Sánchez, F., 1987. Nitrogen-fixing nodules induced by Agrobacterium tumefaciens harboring Rhizobium phaseoli plasmids. Journal of Bacteriology, 169(6), pp.2828-2834. Available at: http://www.ncbi.nlm.nih.gov/pubmed/3584072.

Mayani, N. \& Hapsoh, 2012. Potensi rhizobium dan pupuk urea untuk meningkatkan produksi kedelai (Glycine max L.) pada lahan bekas sawah. Jurnal Ilmu Pertanian KULTIVAR, 5(2), pp.68-75. Available at: http://download.portalgaruda.org/article.php?article=51371\&val=4106.

Miranda, A., Janssen, G., Hodges L., Peralta, E.G. \& Ream, W., 1992. Agrobacterium tumefaciens transfers extremely long T-DNAs by a unidirectional mechanism. Journal of Bacteriology, 174, pp.22882297. Available at: https://doi.org/10.1128/JB.174.7.2288-2297.1992.

Morett, E. \& Segovia, L., 1993. The sigma 54 bacterial enhancer-binding protein family: mechanism of action and phylogenetic relationship of their functional domains. Journal of Bacteriology, 175, pp.6067-6074. Available at: http://www.ncbi.nlm.nih.gov/pubmed/8407777.

Mueller, N.D., Gerber, J.S., Johnston, M., Ray, D.K., Ramankutty, N. \& Foley, J.A., 2012. Closing yield gaps through nutrient and water management. Nature, 490, pp.254-257. Available at: https://doi.org/10.1038/nature11420.

Oldroyd, G.E.D. \& Dixon, R., 2014. Biotechnological solutions to the nitrogen problem. Current Opinion in Biotechnology, 26, pp.19-24. Available at: https://doi.org/10.1016/j.copbio.2013.08.006.

Peters, J.W. \& Szilagyi, R.K., 2006. Exploring new frontiers of nitrogenase structure and mechanism. Current Opinion in Chemical Biology, 10, pp.101-108. Available at: https://doi.org/10.1016/J.CBPA. 2006.02.019.

Reddy PM, James EK, Ladha JK. 2002. Nitrogen Fixation in Rice. In: Leigh GJ. (ed) Nitrogen Fixation at the Millenium. Amsterdam: Elsevier. pp 421-445. 
Pranata, dkk : Prospek Introduksi Regulon nif dari Bakteri Klebsiella pneumoniae ke Dalam Genom Mitokondria ...

Rosmarkam, A. \& N.A. Yuwono. 2002. Ilmu Kesuburan Tanah. Yogyakarta: Kanisius.

Shah, V.K. \& Brill, W.J., 1973. Nitrogenase IV. Simple method of purification to homogeneity of nitrogenase components from Azotobacter vinelandii. Biochimica et Biophysica Acta Bioenergetics, 305(2), pp.445-454. Available at: http://www.ncbi.nlm.nih.gov/pubmed/4354875.

Wang, X., Yang, J.G., Chen, L., Wang, J.L., Cheng, Q., Dixon, R., Wang, Y.P., 2013. Using synthetic biology to distinguish and overcome regulatory and functional barriers related to nitrogen fixation. PLoS ONE, 8(7), pp.e68677. Available at: https://doi.org/10.1371/journal.pone.0068677. 